\title{
Legalitas Transaksi Jual Beli Sepeda Motor Tanpa Bukti Kepemilikan dalam Perspektif Sadd Al-Żarī'Ah
}

\author{
Nahara Eriyanti', Ayu Sarami² \\ UIN Ar-Raniry Banda Aceh', UIN Ar-Raniry Banda Aceh ${ }^{2}$ \\ nahara.eriyanti@ar-raniry.ac.id ${ }^{1}$, ayusarami@gmail.com ${ }^{2}$
}

\begin{abstract}
This study is aimed to find out how the legal status of buying and selling motorbikes without vehicle registration STNK and BPKB, where many of the people of the District of Kebharga, especially Kala Lengkio Village and Mendale Village, conduct transactions of buying and selling motorbikes without STNK and BPKB. In general, buying and selling carried out by the public has fulfilled the legal requirements of buying and selling in Islam, which does not explain in detail that buying and selling motorbikes without the STNK of BPKB is a sale and purchase which is canceled. Unlike the case with the police which states that buying and selling motorbikes without a STNK and BPKB is a canceled sale. Based on the description above that is the focus of research on the formulation of the problem namely: how to buy and sell motorbikes without proof of ownership in the community of the District of Kebayakan and how is its legality from the perspective of sadd al-'ari'ah ?. In this study the author uses the case study research method then analyzed using the theory of sadd al-'ari'ah, then in the technique of collecting data the author uses interviews / interviews. The results of the study that the authors get about buying and selling motorbike transactions without proof of ownership and analyzed using the theory of sadd al-iari' ah that looks at the benefits and mafsadat arising, then the motorcycle sale and purchase transactions without proof of ownership there is a level of understanding that is superior to with benefit, the sale and purchase of the people of the district is a sale that must be prevented and must also be avoided by the community because the sale can cause a lot of damage even though the sale of a motorcycle is a sale that is in accordance with the terms and conditions of the legal sale.
\end{abstract}

Keywords: Buying and selling, Sadd al-żarìah

\begin{abstract}
Abstrak
Penelitian ini ditujujkan untuk mengetahui bagaimana status hukum jual beli sepeda motor tanpa STNK dan BPKB, dimana banyak dari masyarakat yang melakukan transaksi jual beli sepeda motor tanpa adanya STNK dan BPKB. Secara umum jual beli yang dilakukan masyarakat telah memenuhi syarat sah jual beli dalam Islam yang tidak menjelaskan secara rinci bahwa jual beli sepeda motor tanpa adanya STNK dan BPKB adalah jual beli yanag batal. Berbeda halnya dengan pihak kepolisian yang meyatakan bahwasanya jual beli sepeda motor tanpa adanya STNK dan BPKB adalah jual beli yang batal. Berdasarkan uraian d iatas yang menjadi fokus penelitian pada rumusan masalah yaitu: bagaimana praktik jual beli sepeda motor tanpa bukti kepemilikan dan bagaimana legalitasnya dari perspektif sadd al-żaríah. Dalam penelitian ini Penulis menggunakan metode penelitian studi kasus selanjutnya dianalisis menggunakan teori sadd al-żarīah, kemudian dalam teknik mengumpulkan data Penulis menggunakan interview/wawancara. Hasil penelitian yang Penulis
\end{abstract}


dapatkan mengenai transaksi jual beli sepeda motor tanpa bukti kepemilikan dan dianalisis menggunakan teori sadd al-żari’ah yang melihat pada maslahat dan mafsadat yang ditimbulkan, maka dari transaksi jual beli sepeda motor tanpa bukti kepemilikan terdapat tingkat kemafsadatan yang lebih unggul dibandingkan dengan kemaslahatan, maka jual beli yang dilakukan adalah jual beli yang harus dicegah dan juga harus dihindari oleh masyarakat karena jual beli tersebut dapat menimbulkan banyak kerusakan walaupun jual beli sepeda motor adalah jual beli yang telah sesuai dengan rukun dan syarat sah jual beli.

Kata Kunci: Jual beli, Sadd al-żari’‘h

\section{PENDAHULUAN}

Akad jual beli merupakan akad yang paling banyak digunakan untuk pengalihan kepemilikan secara legal. Bahkan dalam sistem hukum diatur dengan jelas bentuk transaksi, konsekuensi dan perlindungan hukum terhadap para pihak. Hal tersebut urgen untuk ditetapkan ketentuan yuridisnya untuk melindungi para pihak dari berbagai tindakan negatif dan eksploitatif yang merugikan pihak penjual dan pembeli.

Semua jenis harta benda dapat diperjualbelikan, selama tidak ada dalil yang mengharamkannya, baik berupa benda yang bergerak dan tidak bergerak. Salah satu yang menjadi objek transaksi yaitu sepeda motor baik yang masih baru maupun sepeda motor bekas, kemampuan finansial biasanya mempengaruhi daya beli masyarakat karena itu tidak semua mampu membeli sepeda motor baru dikarenakan harganya yang mahal. Sehingga sebagai alternatif sebagian masyarakat membeli sepeda motor bekas pakai baik yang sudah setengah pakai, maupun yang sudah tua sesuai dengan keinginan, kebutuhan, dan kemampuan finansialnya.

Harga dan jenis sepeda motor bekas sangat bervariasi, sehingga dibutuhkan keahlian pihak pembeli untuk mengetahui keadaan fisik kendaraan yang akan dibeli agar tidak rugi. Harga sepeda motor setengah pakai jauh lebih murah dibandingkan harga sepeda motor baru. Di kalangan masyarakat transaksi sepeda motor seken ini sangat variatif, mulai dari motor yang baru dipakai beberapa bulan saja sehingga kondisinya sangat gress, dan juga terdapat motor yang kondisinya sudah sangat jelek, bahkan terdapat juga motor yang harganya sangat murah meskipun kondisinya masih sangat bagus, dan harganya tidak mahal, namun tidak adanya surat-surat penting seperti STNK dan BPKB. Hal ini menyebabkan pihak penjual membanderol harga sepeda motor ini dengan harga di bawah standar harga yang ditetapkan untuk harga sepeda motor bekas sebagaimana mestinya.

\section{METODE PENELITIAN}

Dalam penelitian ini metode yang digunakan adalah metode studi kasus, yaitu suatu penelitian kualitatif yang berusaha menemukan makna, 
menyelidiki proses, dan memperoleh pengertian dan pemahaman yang mendalam dari individu, kelompok atau situasi terhadap peristiwa yang sedang berlangsung (Emzir, 2014: 14) yang bertujuan untuk memecahkan suatu permasalahan dengan cara mengumpulkan data-data yang berkaitan dengan permasalahan dan mencari pokok permasalahan tersebut (Nasution, 2003: 32) mengenai tentang status jual beli sepeda motor tanpa adanya STNK dan BPKB. Metode kualitatif yang digunakan adalah metode untuk menganalisis dan memecahkan masalah yang berkenaan pada legalitas transaksi jual beli sepeda motor tanpa bukti kepemilikan di Kecamatan Kebayakan dalam perspektif sadd al-żarí‘ Praktik transaksi jual beli yang sering terjadi di kalangan masyarakat Kebayakan, tanpa memperdulikan akibat yang akan timbul kedepannya.

Teknik yang digunakan dalam pengumpulan data menggunakan teknik wawancara. Wawancara merupakan tanya jawab antara pewawancara dengan yang narasumber untuk mendapatkan data primer yang berhubungan dengan permasalahan yang ditelit.

\section{PEMBAHASAN}

\section{Praktik jual beli sepeda motor tanpa bukti kepemilikan pada masyarakat}

Jual beli merupakan menukar suatu barang dengan barang lainnya atau menukar barang dengan uang diiringi dengan melepaskan hak kepemilikan dari yang satu kepada yang lain atas dasar saling merelakan dan saling bermanfaat yang berlaku untuk selamanya bukan sementara. Dalam konsep fikih muamalah, para fukaha telah melakukan ijtihad dalam membuat teori jual beli dari nas-nas Alqur'an dan Hadis. Konsep jual beli dalam fikih ini sangat implementatif dan dapat diaplikasikan oleh setiap mukallaf dalam transaksi jual beli. salah satu hal yang substantif dalam jual beli, fukaha telah menetapkan rukun dan syarat jual beli yang sangat penting untuk menetapkan legalitas transaksi jual beli yang dilakukan fukaha. Hukum asal dari jual beli adalah boleh selama jual beli tersebut memenuhi syarat dan rukun jual beli dalam Islam.

Para fukaha telah memformulasikan syarat sah jual beli, di antara syaratnya yaitu objek transaksi jual beli merupakan barang yang baik dan tidak memiliki cacat yang disembunyikan dari pihak pembeli. Syarat penting lainnya adalah pihak pembeli mengetahui kriteria barang yang akan diperjualbelikan, seperti jenis, kualitas, maupun kuantitas barangnya, dan dalam pelaksanaan transaksi jual beli tersebut harus terhindar dari unsur tipuan dan paksaan (Nasroen, 2007: 119). Begitu juga menurut Syafi'iyah, ma'qūd 'alaih harus diketahui oleh pihak yang melakukan akad, baik bendanya, kadarnya, maupun sifatnya dan harus terbebas dari unsur cacat (Ahmad, 2015: 98). 
Semua jenis harta benda dapat diperjualbelikan, selama tidak ada dalil yang mengharamkannya, baik berupa benda yang bergerak dan tidak bergerak. Salah satu yang menjadi objek transaksi yaitu sepeda motor baik yang masih baru maupun sepeda motor bekas, kemampuan finansial biasanya mempengaruhi daya beli masyarakat karena itu tidak semua mampu membeli sepeda motor baru dikarenakan harganya yang mahal. Sehingga sebagai alternatif sebagian masyarakat membeli sepeda motor bekas pakai baik yang sudah setengah pakai, maupun yang sudah tua sesuai dengan keinginan, kebutuhan, dan kemampuan finansialnya.

Seiring berkembangnya zaman, transaksi jual beli sepeda motor semakin bervariasi, sebagaimana jual beli yang dilakukan oleh masyarakat yaitu jual beli sepeda motor yang dilakukan adalah jual beli sepeda motor yang tidak memiliki STNK dan BPKB. Beberapa kasus yang ditemukan di lapangan, banyak dari kalangan masyarakat yang melakukan transaksi jual beli sepeda motor tanpa adanya STNK dan BPKB didorong oleh kebutuhan ekonomi. Harga dan jenis sepeda motor bekas sangat bervariasi, sehingga dibutuhkan keahlian pihak pembeli untuk mengetahui keadaan fisik kendaraan yang akan dibeli agar tidak rugi. Harga sepeda motor setengah pakai jauh lebih murah dibandingkan harga sepeda motor baru. Di kalangan masyarakat transaksi sepeda motor seken ini sangat variatif, mulai dari motor yang baru dipakai beberapa bulan saja sehingga kondisinya sangat gress, dan juga terdapat motor yang kondisinya sudah sangat jelek, bahkan terdapat juga motor yang harganya sangat murah meskipun kondisinya masih sangat bagus, dan harganya tidak mahal, namun tidak adanya surat-surat penting seperti STNK dan BPKB. Hal ini menyebabkan pihak penjual membanderol harga sepeda motor ini dengan harga di bawah standar harga yang ditetapkan untuk harga sepeda motor bekas sebagaimana lazimnya (Sahrian, 2019).

Pihak pembeli sering sekali dihadapkan dengan berbagai kemungkinan pada pembelian sepeda motor yang tidak memiliki suratsurat yang berkaitan dengan kendaraan. Jawaban yang sering diberikan oleh pihak penjual adalah sepeda motor yang akan dijual merupakan miliknya, namun surat-surat yang terkait dengan kendaraan tersebut tidak ada disebabkan karena hilang atau musibah. Hasil wawancara dengan salah seorang pembeli beranggapan bahwasanya jual beli yang dilakukan adalah jual beli yang sah karena telah memenuhi syarat dan rukun jual beli (Abdullah, 2010: 130). Dijelaskan juga dalam Kitab Undang-undang Hukum Perdata Buku ke III Bab V Pasal 1459, hak milik atas barang yang dijual tidak pindah kepada pembeli selama barang yang diperjualbelikan belum diserahkan (Niniek, 2007:358). Untuk membuktikan kepemilikan terhadap barang maka harus disertai dengan adanya barang tersebut (Abdulkadir Muhammad, 2005). Seperti dijelaskan dalam pasal 1977 KUHP, barang siapa menguasai barang 
bergerak yang tidak berupa bunga atau piutang yang tidak harus dibayar atas tunjuk, dianggap sebagai pemiliknya sepenuhnya.

Setiap orang yang mengaku mempunyai suatu hak atas suatu barang, atau menunjuk suatu peristiwa untuk meneguhkan haknya itu atau untuk membantah suatu hak orang lain, wajib membuktikan adannya hak itu atau kejadian yang dikemukakan itu dengan beberapa cara, yaitu melalui bukti secara tertulis, bukti dengan mempunyai saksi, persangkaan, pengakuan, dan sumpah (Niniek, 2007: 465).

Pembuktian secara tertulis dilakukan dengan tulisan otentik atau dengan tulisan di bawah tangan, pembuktian dengan saksi-saksi diperkenankan dalam segala hal yang tidak dikecualikan dalam undangundang yang mana tiap kesaksian harus disertai keterangan tentang bagaimana saksi mengetahui kesaksiannya, pembuktian dengan persangkaan merupakan kesimpulan yang oleh undang-undang atau oleh hakim ditarik dari suatu peristiwa yang diketahui umum ke arah suatu peristiwa yang tidak diketahui umum, pengakuan yang diberikan di hadapan hakim adalah pembuktian yang sempurna terhadap orang yang telah memberikannya, baik sendiri maupun dengan perantara seseorang yang diberi kuasa khusus untuk itu, dan sumpah merupakan suatu upaya yang dilakukan agar dengan sumpah tersebut dapat memutuskan suatu perkara (Niniek, 2007: 587).

Terkait dengan transaksi jual beli pada transaksi sepeda motor, telah diatur dalam ketetapan Undang-Undang Nomor 22 Tahun 2009 tentang Lalu Lintas dan Angkutan Jalan, pada Pasal 64 setiap kendaraan bermotor wajib diregistrasikan yang meliputi kendaraan bermotor baru, perubahan identitas kendaraan bermotor dan pemilik, perpanjangan kendaraan bermotor, dan registrasi pengesahan kendaraan bermotor, dilanjutkan dengan Pasal 68, setiap kendaraan bermotor yang dioperasikan dijalan wajib dilengkapi dengan Surat Tanda Nomor Kendaraan Bermotor dan Buku Pemilik Kendaraan Bermotor (UU 2/2009: P 64).

Hal ini juga dijelaskan dalam Peraturan Presiden RI No. 5 Tahun 2015 tentang Penyelenggaraan Sistem Administrasi Manunggal Satu Atap Kendaraan Bermotor, Pasal 1 angka 9 menyebutkan bahwa STNK dan BPKB merupakan bukti registrasi kendaraan bermotor yang bisa diartikan juga dengan sertifikat kepemilikan terhadap kendaraan yang diterbitkan oleh Polri yang berlaku sampai kendaraan tidak dipindahtangankan. Dari keterangan tersebut tidak ditemukan penjelasan yang rinci terkait batalnya jual beli sepeda motor tanpa adanya bukti kepemilikan seperti STNK dan BPKB.

Polisi Lalu Lintas mengatakan bahwa STNK dan BPKB merupakan suatu bukti dari kepemilikan terhadap sepeda motor dan merupakan syarat sah milik dan menyatakan bahwasanya tidak akan bisa dikatakan sah jual beli sepeda motor jika tidak dilengkapi dengan surat-surat 
kepemilikan seperti halnya Surat Tanda Nomor Kendaraan (STNK) dan Buku Pemilik Kendaraan Bermotor (BPKB). Jika seseorang memiliki kendaraan bermotor tapi tidak memiliki surat-surat kepemilikan maka bisa dikatakan bahwa kendaraan tersebut bukan miliknya (Syaifullah, 2019).

Pembuktian dalam memiliki barang akan menghindarkan dari kecekcokan ke depannya, baik dalam mengadakan bukti tertulis, mengadakan saksi, maupun pembuktian lainnya. Seperti yang dijelaskan dalam Alqur'an Surah al-Baqarah ayat 282.

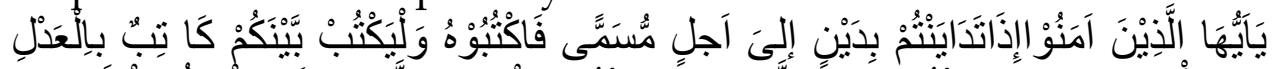

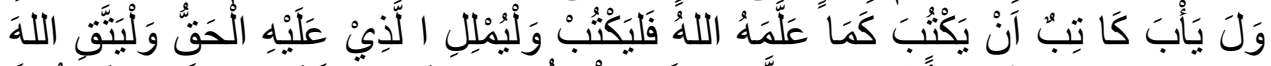

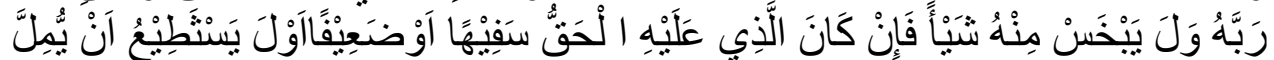

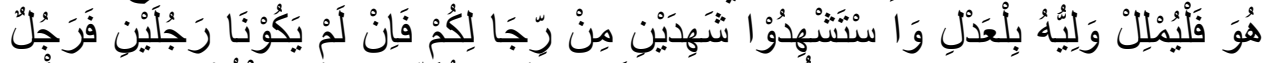

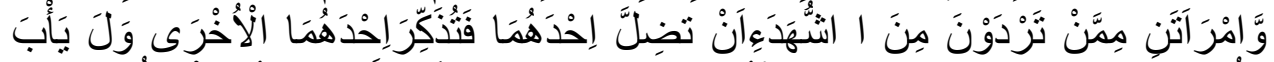

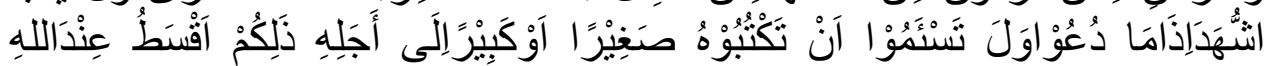

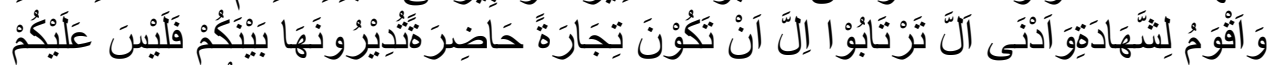

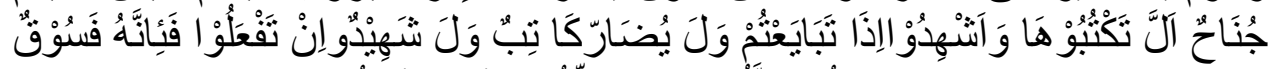

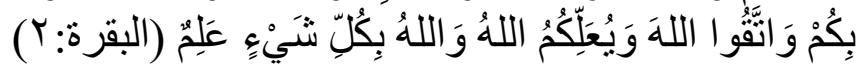

Hai orang-orang yang beriman, apabila kamu bermu'amalah tidak secara tunai untuk waktu yang ditentukan, hendaklah kamu menuliskannya. Dan apabila kamu melakukan utang-piutang untuk waktu yang ditentukan, hendaklah seorang penulis di antara kamu menuliskannya dengan benar. dan janganlah penulis enggan menuliskannya sebagaimana Allah mengajarkannya, maka hendaklah ia menulis, dan hendaklah orang yang berhutang itu mengimlakkan apa yang akan ditulis itu, dan hendaklah ia bertakwa kepada Allah Tuhannya, dan janganlah ia mengurangi sedikitpun daripada hutangnya. jika yang berhutang itu orang yang lemah akalnya atau lemah keadaannya atau dia sendiri tidak mampu mengimlakkan, Maka hendaklah walinya mengimlakkan dengan jujur. dan persaksikanlah dengan dua orang saksi dari orang-orang lelaki di antaramu. jika tak ada dua oang lelaki, Maka boleh seorang lelaki dan dua orang perempuan dari saksi-saksi yang kamu ridhai, supaya jika seorang lupa Maka yang seorang mengingatkannya. janganlah saksi-saksi itu enggan memberi keterangan apabila mereka dipanggil; dan janganlah kamu jemu menulis hutang itu, baik kecil maupun besar sampai batas waktu membayarnya. yang demikian itu, lebih adil di sisi Allah dan lebih menguatkan persaksian dan lebih dekat kepada tidak menimbulkan keraguanmu. Tulislah mu'amalahmu itu, kecuali jika mu'amalah itu perdagangan tunai yang kamu jalankan di antara kamu, Maka tidak ada dosa bagi kamu, jika kamu tidak menulisnya. dan persaksikanlah apabila kamu berjual beli; dan janganlah penulis dan saksi saling sulit menyulitkan. jika kamu lakukan (yang demikian), Maka Sesungguhnya hal itu adalah suatu kefasikan pada dirimu. dan bertakwalah kepada Allah; 
Allah mengajarmu; dan Allah Maha mengetahui segala sesuatu" (Q.S. alBaqarah[2]: 282).

Ayat di atas merupakan ketentuan untuk utang piutang, tetapi, apabila transaksi jual beli dilakukan secara tunai atau kontan dan serah terima barang dan pembayarannya, maka tidak ada larangan jika tidak menuliskannya, namun mengenai transaksi jual beli, ayat di atas menjelaskan tentang perintah untuk membuat persaksian atas hak orang yang melakukan transaksi jika memakai tempo waktu atau tidak memakai tempo waktu. Dengan kata lain, ayat tersebut memerintahkan agar membuat persaksian atas hak terhadap transaksi jual beli yang dilakukan dalam keadaan apapun, yang mana menurut jumhur ulama kandungan ayat di atas adalah anjuran dan petunjuk, bukan sebagai perintah wajib (Imam, 200: 198).

\section{Legalitas Transaksi Jual Beli Sepeda Motor Tanpa Adanya Bukti Kepemilikan Berdasarkan Perspektif Sadd Al-Żar'̄A $h$}

Kepemilikan merupakan penguasaan terhadap seuatu barang yang dapat bertindak bebas terhadap barang yang dimiliki, baik untuk dijual atau akan digadaikan selama tidak bertentangan syarak (Mardani, 2013: 66). Arti kepemilikan juga dapat dipahami sebagai penguasaan khusus terhadap barang yang dimiliki tanpa ada gangguan orang lain untuk mengambil manfaat barangnya, kecuali dengan hal tertentu yang dibenarkan oleh syarak (Ahmad,70). Ulama fikih membagi kepemilikan dalam dua bagian (Narun, 34).

1. Milk al-tāmm, adalah kepemilikan yang sempurna. yaitu pemilikan harta yang dapat dikuasai antara benda dan manfaatnya sekaligus (Hendi, 2016: 40). Kepemilikan sempurna juga dikatakan sebagai kepemilikan terhadap barang secara penuh yang memberikan kewenangan kepada si pemilik untuk melakukan berbagai macam kegiatan terhadap harta yang dimilikinya sesuai dengan kebenaran syarak yang telah ditetapkan(Ahmad, 73). Milk at-tāmm memiliki beberapa ciri-ciri khusus, yaitu harta yang dimiliki baik benda dan manfaatnya bersifat sempurna sejak awal kepemilikan, materi dan manfaatnya sudah ada sejak kepemilikan benda itu, tidak adanya batasan waktu dalam memiliki benda tersebut karena milk seperti ini bersifat mutlak, apabila harta yang dimiliki merupakan kepunyaan bersama, maka masing-masing orang bebas menggunakan miliknya. Kepemilikan seperti ini biasanya dapat diperoleh melalui transaksi jual beli (Mardani, 68).

2. Milk naqīșah, yaitu kepemilikan terhadap benda yang hanya memiliki salah satu dari benda tersebut ketika memiliki manfaatnya maka tidak diikuti dengan kepemilikan zatnya dan ketika memiliki zatnya maka tidak dapat memiliki manfaatnya, kepemilikan seperti ini sering 
disebut dengan kepemilikan tidak sempurna (Sohari, 2011: 37). Kepemilikan berupa penguasaan terhadap benda atau zatnya disebut milik raqabah, sedangkan kepemilikan terhadap penguasaan terhadap kegunaanya disebut milik manfaat (Hendi, 2016: 40). ciri-ciri khusus milk naqișah yaitu, kepemilikan harta tersebut dibatasi oleh waktu, tempat dan sifatnya, adanya kewajiban mengeluarkan biaya pemeliharaan bagi orang-orag yang memanfaatkan harta tersebut, adanya juga kewajiban bagi orang yang memanfaatkan barang untuk mengembalikan harta tersebut kepada pemiliknya, jika dimintai oleh pemiliknya untuk dikembalikan (Mardani,, 2013: 68). Milk naqișah terjadi melalui beberapa cara, diantaranya melalui pinjam meminjam, sewa menyewa, wakaf, wasiat, dan hibah.

Ada beberapa cara untuk memperoleh pemilikan harta dalam Islam yang ditetapkan oleh para ulama fikih, yaitu (Nasrun, 32); 1) melalui penguasaan terhadap harta yang belum pernah sama sekali dimiliki oleh seseorang atau perlembagaan, misalnya seseorang mengambil tanah dari dalam sungai yang belum dimiliki orang lain dan kemudian membawanya pulang ke rumahnya, maka secara otomatis tanah yang diambil akan menjadi miliknya; 2) melalui suatu transaksi yang dilakukan antara seseorang dengan seseorang atau suatu lembaga, misalnya melalui transaksi hibah, jual beli, dan juga wakaf; 3) hasil dari harta yang telah dimiliki seseorang, baik buahnya maupun hal lainnya yang muncul secara alami; 4) melalui peninggalan seseorang yang diberikan terhadap seseorang lainnya, misalnya harta warisan.

Dari keempat cara tersebut seseorang bisa menjadi pemilik atas suatu harta, yang mana ia bebas mengembangkan hartanya dan dapat mencari keuntungan sebanyak yang ia mau dengan cara yang jujur dan sesuai dengan ketentuan Islam. Seperti halnya memiliki sepeda motor yang didapatkan melalui transaksi jual beli. Islam tidak menjelaskan secara khusus tentang kedudukan bukti kepemilikan dalam syarat sah jual beli, oleh karena itu jual beli sepeda motor tanpa adanya bukti kepemilikan tetap dianggap sah oleh masyarakat Kecamatan Kebayakan. Begitu pula halnya dengan peraturan hukum dagang yang tidak menjelaskan secara rinci tentang kedudukan bukti kepemilikan terhadap sahnya suatu jual beli. Menghadapi permasalahan ini, untuk menetapkan suatu hukum, perlu di timbang kadar kemaslahatan dan kemudaratan yang akan timbul jika transaksi jual beli seperti ini dilakukan. Oleh karena itu perlu dianalisis dengan metode sadd al-żarīa ah, yang mana metode ini adalah metode yang mencegah atau menutup suatu perbuatan agar perbuatan tersebut tidak sampai kepada perbuatan yang dilarang atau suatu perbuatan yang dapat menimbulkan kerusakan dengan menimbang antara kemaslahatan dan kemudaratan dari suatu perbuatan. 
Sadd al-żarī‘ah merupakan salah satu metode pengambilan keputusan hukum dalam Islam, namun sebagian ulama ada yang menempatkannya dalam deretan dalil-dalil syara' yang tidak disepakati oleh ulama. Ditempatkannya żarī'ah sebagai salah satu dalil dalam menetapkan hukum meskipun diperselisihkan penggunaannya, mengandung arti bahwa meskipus syarak tidak menetapkan secara jelas mengenai hukum suatu perbuatan, namun karena perbuatan itu ditetapkan sebagai wāsilah dari suatu perbuatan yang dilarang secara jelas, maka hal ini menjadi petunjuk atau dalil bahwa hukum wāsilah itu adalah sebagaimana hukum yang ditetapkan syarak terhadap perbuatan pokok (Amir, 2008: 400).

Seperti yang dijelaskan dalam QS. an-Nur ayat: 31.

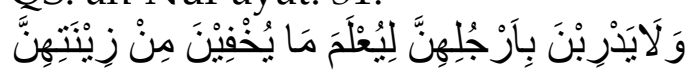

Dan janganlah mereka memukulkan kakinya agar diketahui perhiasan yang mereka sembunyika (QS. an-Nur[24]: 31).

Hukum asal wanita memukulkan atau menghentak-hentakkan kaki di tanah itu boleh, namun karena menyebabkan perhiasannya yang tersembunyi dapat diketahui orang, sehingga akan menimbulkan rangsangan bagi yang melihat dan mendengar, apalagi jika dilakukan di hadapan laki-laki yang bukan mahramnya sehingga bisa menjadi fitnah antara laki-laki dan wanita tersebut, maka perbuatan itupun dilarang oleh Allah Swt.

Penetapan hukum berdasarkan sadd al-żarī‘ah adalah cara menetapkan suatu hukum berdasarkan kepada akibat suatu perbuatan, akibat suatu perbuatan dapat berimplikasi kepada maslahat atau mafsadat, karena itu implikasi suatu hukum yang mengandung maslahat maka mengandung hukum mubah, sedangkan implikasi hukum yang mengandung mafsadat akan mengandung hukum haram atau makruh (Rahman, 2015: 82). Kadar maslahat mafsadat dapat menjadi dasar untuk menentukan nilai yang tepat bagi perbuatan sehingga hukumnya dapat diputuskan, dan hal ini dapat menjadi pertimbangan apakah nilai pada asal yang diberlakukan terhadap suatu kasus atau nilai pada efek yang ditimbulkannya, hal ini menjadi kriteria bagi penerapan sadd al-żarī'ah yang menjadi mekanisme untuk menetapkan nilai suatu perbuatan (Rahman, 82). Penggunaan metode sadd al-żarī‘ah ini adalah tindakan preventif dalam terminologi Hukum Islam yang bertujuan untuk melarang suatu perbuatan yang menurut hukum agama diperbolehkan, namun karena mengandung atau membawa kepada unsur kemudaratan atau kerusakan, maka perbuatan tersebut dilarang (Rahman, 83).

Sebagaimana dijelaskan dalam kaidah fiqhiyyah yang dapat dijadikan dasar sadd al-żarīah sebagai metode istinbat hukum dan sebagai petunjuk (dalil), yaitu:

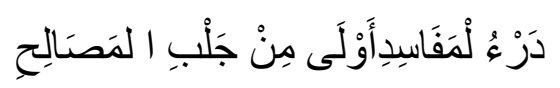


Menolak keburukan (mafsadah) lebih diutamakan daripada meraih kebaikan.

Apabila didalam suatu perbuatan terdapat mafsadat yang lebih besar dari pada manfaat, maka harus mendahulukan menghilangkan mafsadat tersebut dari pada mengambil manfaatnya.

Melihat dari unsur kemaslahatannya, perbuatan yang dilakukan masyarakat Kecamatan Kebayakan adalah suatu perbuatan yang menimbulkan banyak manfaat bagi kehidupan masyarakat, terutama dari segi pemenuhan kebutuhan perekonomian. Masyarakat Kecamatan Kebayakan melakukan transaksi jual beli sepeda motor tanpa memiliki bukti kepemilikan karena harga yang ditawarkan kepada mereka relif lebih murah dan dapat terjangkau oleh perekonomian mereka, sehingga mereka dapat lebih mudah menjalankan aktivitas dalam mencari rezeki dan melengkapi kebutuhan sehari-hari mereka.

Beberapa risiko yang timbul akibat membeli sepeda motor yang tidak dilengkapi dengan bukti kepemilikan, seperti halnya akan dianggap sebagai penadah jika kendaraan yang dibeli merupakan kendaraan yang berasal dari hasil curian, tidak dapat digunakan di jalan raya karena akan terkena razia dan jika terkena razia maka kendaraan tersebut tidak akan bisa diambil kembali sebelum menunjukkan bukti-bukti kepemilikan kendaraan, dan risiko lainnya adalah apabila terjadi persengketaan mengenai sepeda motor tersebut maka yang memiliki kendaraan atau yang telah membeli kendaraan tidak dapat menyatakan bahwa sepeda motor tersebut miiknya. Melihat dari beberapa risiko yang dapat terjadi ketika melakukan pembelian sepeda motor tanpa bukti kepemilikan, maka hal tersebut menimbulkan sebuah kemafsadatan.

Secara umum, praktik yang terjadi di masyarakat telah memenuhi rukun dan syarat jual beli, di mana yang melakukan jual beli merupakan masyarakat yang telah balig dan berakal, mereka melakukan transaksi jual beli dengan kemauan mereka sendiri dengan mempertimbangkan manfaat yang akan diperoleh dari barang yang dibeli. Proses jual beli yang dilakukan dalam transaksi jual beli di Kecamatan Kebayakan diawali dengan proses tawar menawar sampai mereka mendapatkan kesepakatan dan berakhir dengan terjadinya transaksi jual beli.

Masyarakat menganggap bahwa jual beli yang dilakukan adalah jual beli yang sah dan banyak manfaat yang didapatkan dari barang yang dibeli. Namun sebaliknya pihak kepolisian menyatakan bahwasanya jual beli sepeda motor yang tidak memiliki bukti kepemilikan adalah jual beli yang tidak boleh dilakukan. Setiap pemilik kendaraan bermotor harus meregistrasikan kendaraannya, dengan tujuan untuk tertib administrasi, pengendalian dan pengawasan kendaraan bermotor yang dioperasikan di Indonesia, mempermudah penyidikan pelanggaran atau kejahatan, perencanaan, operasional manajemen dan Rekayasa Lalu Lintas dan 
Angkutan Jalan, dan perencanaan pembangunan nasional. Bahkan banyak akibat yang akan timbul jika membeli kendaraan yang tidak dilengkapi dengan bukti-bukti kepemilikan.

Ditinjau dari segi kekuatannya sebagai hujjah dalam menetapkan hukum, kemaslahatan suatu perbuatan dapat dilihat dari tiga tingkat, yaitu:

1. Maslahah darúriyyāt yaitu kemaslahatan yang keberadaannya sangat dibutuhkan oleh kehidupan manusia, yang mana tidak akan bearti kehidupan manusia jika kehilangan satu di antara ke lima prinsip dalam tingkatan maslahah ḍarúriyyāt ini.

a. Allah memerintahkan untuk memelihara agama, oleh karena itu Allah melarang murtad agar agamanya terjaga

b. Allah memerintahkan memelihara jiwa, oleh karena itu Allah melarang membunuh

c. Melarang meminum minuman keras agar terpeliharanya akal

d. Melarang berzina agar terjaganya keturunan

e. Melarang mencuri agar terjaganya harta.

Kebutuhan ini merupakan segala yang menjadi sendi kehidupan manusia yang harus tetap ada agar kemaslahatan mereka terjaga. Apabila kelima sendi ini tidak terjaga dengan baik maka kehidupan manusia akan mengalami kekacauan karena tidak terwujudnya kemaslahatan di dunia dan di akhirat.

2. Maslahah hājiyyāat, adalah kemaslahatan yang tingkatannya berada di bawah ḍarúriyyāt, tetapi secara tidak langsung kemaslahatan dalam memenuhi kebutuhan menuju ke arah kebutuhan pokok ḍarúriyyāt, kebutuhan ini adalah segala sesuatu yang dihajatkan oleh manusia untuk menghilangkan kesulitan yang dirasakan, yang apabila tidak tercapainya aspek ini maka tidak sampai mengancam sendi kehidupan manusia.

Contoh dari Maslahah hạjiyyāat ini adalah pemilikan sepeda motor oleh manusia untuk memenuhi kebutuhannya dalam mencari rezeki, seperti halnya masyarakat yang ada di Kecamatan Kebayakan, yang membeli sepeda motor untuk memudahkan dalam mencar rezeki dan memenuhi kebutuhan hidup masyarakat sehingga dapat menghasilkan harta, jika masyarakat tidak memiliki sepeda motor maka masyarakat akan kesusahan dalam memenuhi kehidupan dan kesusahan dalam mengumpulkan harta, sehingga jika tidak memiliki harta maka akan berdampak pada pemeliharaan harta.

3. Maslahah tahsiniyah merupakan maslahah yang kebutuhan hidup manusia tidak sampai tingkat ḍarúriyyāt dan hạjiyyāat, namun kebutuhan tersebut perlu di penuhi dalam rangka memberi kesempurnaan dan keindahan bagi hidup manusia, Maslahah 
taḥsiniyah ini juga berkaitan dengan lima pokok kebutuhan manusia. Misalnya dibidang adat atau kebiasaan lainnya.

Melihat dari tingkatan kemaslahatannya, memiliki sepeda motor adalah tingkat kebutuhan yang berada di tingkat kedua, yang mana sepeda motor ini dianggap sebagai salah satu bentuk kebutuhan masyarakat yang bisa digunakan untuk berbagai macam kebutuhan. Jika melihat langsung ke lapangan, maka sepeda motor banyak digunakan untuk membantu meringankan pekerjaan masyarakat dalam mencari rezeki dan apabila masyarakat tersebut tidak memiliki sepeda motor, maka secara langsung mereka mengalami kesulitan dalam memenuhi kebutuhan hidup mereka.

Masyarakat menjadikan sepeda motor sebagai alat transportasi andalan dalam mencari harta benda, selain sepeda motor ini bisa mempercepat perjalanan mereka menuju tempat sumber rezeki bagi mereka, sepeda motor ini juga bisa dijadikan alat pengangkut barang, seperti mengangkut bibit kopi yang dibawa keperkebunan yang berada di daerah pergunungan, namun di sini sepeda motor yang digunakan oleh masyarakat adalah sepeda motor yang dibeli tanpa dilengkapi dengan bukti kepemilikan.

Mafsadat juga memiliki tiga tingkatan seperti halnya tingkatan pada maslahat, yaitu: Darúriyyāt, hājizyyāat, dan taḥsinniyah. Ketiga tingkatan ini memiliki hubungan yang sangat erat, menurut al-syathibi yaitu:

a. Darúriyyāt merupakan dasar bagi hājiyyāat, dan tahsinniyah.

b. Apabila terjadi kerusakan pada ḍarúriyyāt, maka akan menyebabkan kerusakan pada hạjiyyāat, dan taḥsīniyah.

c. Kerusakan yang terjadi pada hājiyyāat dan taḥsinniyah tidak akan menyebabkan kerusakan pada ḍarúriyyāt.

d. Keperluan dan perlindungan hājiyyāat dan taḥsīniyah perlu dipelihara demi kelestarian ḍarúriyyāt.

Transaksi jual beli sepeda motor tanpa bukti kepemilikan yang dilakukan oleh sebagian masyarakat adalah suatu perbuatan jual beli yang mendatangkan kemaslahatan yang tingkatan maslahatnya berada pada tingkat kedua, yaitu hājiyyāat yang berguna untuk pemenuhan kebutuhan seseorang, namun apabila dilihat dari risiko yang ditimbulkan akibat melakukan transaksi jual beli sepeda motor tanpa bukti kepemilikan, perbuatan ini menimbulkan timbulnya mafsadat pada tingkat pertama, yaitu ḍáuriyyāt, yang mana apabila salah satu dari risiko memiliki kendaraan sepeda motor tanpa bukti kepemilikan terjadi, maka seseorang akan kehilangan hartanya.

Selain kehilangan harta, efek mafsadat bisa meluas yang mana dapat mengancam pada pemeliharaan jiwanya. Karena apabila seseorang mempunyai sepeda motor namun tidak memiliki surat-surat yang terkait, maka kemungkinan dapat dituduh sebagai pencuri atau dituduh sebagai 
seorang penadah. Apabila hal tersebut terjadi, maka seseorang akan dikenai hukuman yang membawa seseorang ke jalur hukum dan membawanya ke dalam permasalahan besar yang mafsadatnya sampai pada tingkat darúriyyāt.

Kebijakan pemerintah seharusnya ditetapkan dalam UndangUndang dagang, yang mengatur permasalahan jual beli sepeda motor untuk menjadi tindakan preventif agar masyarakat tidak terjerumus ke dalam permasalahan seperti ini. Selain itu, penetapan undang-undang dagang tentang jual beli sepeda motor juga perlu untuk singkronisasi antara Undang-Undang dagang dengan Undang-Undang lalu lintas, agar tidak terjadi permasalah. Seperti halnya kaidah fiqhiyah yang berbunyi:

Keputusan hakim dalam ijtihad dapat menghilangkan persengketaan.

Maksud dari kaidah di atas adalah suatu ketetapan hakim (pemerintah) dapat melenyapkan suatu perbedaan pendapat di antara masyarakat agar tidak terjadi kekeliruan yang menyebabkan mereka terjerumus dalam perbuatan yang mengandung kemafsadatan.

\section{KESIMPULAN}

Transaksi jual beli sepeda motor yang dilakukan di kalangan masyarakat adalah transaksi yang telah memenuhi rukun dan syarat sah jual beli. Namun terkait dengan tidak adanya surat-surat bukti kepemilikan, seperti Surat Tanda Nomor Kendaraan (STNK) dan Buku Pemilik Kendaraan Bermotor (BPKB), pihak Polisi Lalu Lintas (POLANTAS) menyatakan bahwasanya jual beli sepeda motor yang tidak dilengkapi dengan bukti-bukti kepemilikan adalah jual beli yang batal atau tidak sah karena STNK dan BPKB merupakan surat yang menyatakan bahwa kendaraan tersebut adalah milik seseorang. Pada dasarnya Islam tidak menjelaskan secara khusus tentang kedudukan bukti kepemilikan dalam syarat sah jual beli, begitu pula halnya dengan peraturan hukum dagang yang tidak menjelaskan tentang kedudukan bukti kepemilikan terhadap sahnya suatu jual beli. Oleh karena itu jual beli yang dilakukan adalah jual beli yang sah, selama benda yang menjadi objek jual beli ini adalah benda milik penjual yang dibuktikan dengan penjelasan dari beberapa pihak sebagai saksi dan bukan dari hasil tindakan yang dilarang.

Tinjauan sadd al-żarīah terhadap transaksi jual beli sepeda motor tanpa bukti kepemilikan adalah melihat pada maslahat dan mafsadat yang ditimbulkan dari transaksi jual beli sepeda motor tanpa bukti kepemilikan. Merujuk pada tingkatan kemaslahatannya, memiliki sepeda motor adalah tingkat kebutuhan yang berada di tingkat kedua (häjiyyāat), yang mana sepeda motor ini dianggap sebagai salah satu bentuk kebutuhan masyarakat yang bisa digunakan untuk berbagai macam kebutuhan. Apabila melihat dari segi mafsadat yang ditimbulkan ketika 
melakukan transaksi jual beli sepeda motor tanpa bukti kepemilikan, maka tingkatan kemafsadatannya berada ditingkat yang pertama (darúriyyāt) yaitu apabila melakukan transaksi jual beli sepeda motor tanpa bukti kepemilikan maka banyak risiko yang dapat terjadi salah satunya adalah akan kehilangan sepeda motor tersebut yang berakibatkan tidak terjaganya harta. Ketika kemafsadatan lebih unggul dari pada kemaslahatan, maka hal yang harus pertama kali dilakukan adalah menghindari kemafsadatan tersebut agar tidak terjadinya kerusakan di kemudian hari. Oleh karena itu, jual beli sepeda motor tanpa bukti kepemilikan harus dilarang oleh pemerintah dengan cara menetapkan aturan tentang syarat sah kepemilikan dalam jual beli sepeda motor dan juga harus dihindari oleh masyarakat karena jual beli tersebut dapat menimbulkan banyak kerusakan walaupun jual beli sepeda motor adalah jual beli yang telah sesuai dengan rukun dan syarat sah jual beli.

\section{DAFTAR PUSTAKA}

Abdulkadir Muhammad. (2003). Hukum Perdata Indonesia. Citra Aditya Bakti.

Amir Syarifuddin.(2008). Ushul Fiqh, cet. 2. Jakarta: Prenada Media Grup.

Dara Lidia, Jabbar Sabil, \& Syarifuddin Usman, Eksistensi Bitcoin dalam Perspektif Maqāșid al-Syar'ìyah, "Petita: Jurnal Kajian Ilmu Hukum dan Syariah, Vol. 2, No2 (2018). Diakses melalui http://jurnal.ar.raniry.ac.id/index.php/petita/indexISSN-P: 25028006 ISSN-E: 2549-8274, tanggal 30 November 2019.

Al imam Abul Fida Isma'il Ibnu Kasir ad-Dimasyqi. (2000) Tafsir Ibnu Kasir, juz 3. Bandung: Sinar Baru Algensindo.

Nasution. (2003). Metode Research, Penelitian Ilmiah, cet. 6. Jakarta: Bumi Aksara.

Niniek Suparni. (2007). Kitab Undang-Undang Hukum Perdata, cet. 7. Jakarta: Rineka Cipta.

Rahman Ambo Masse. (2015). Figh Ekonomi Syariah, Antara Realitas dan Kontekstual. Yogyakarta: Trust Media Publishing. 